\title{
Transformation of the System of Public Administration in a Network Economy
}

\author{
NATALYA METELENKO ${ }^{1}$, LIUDMYLA PASHKO ${ }^{2}$, NATALIIA GRYNCHUK ${ }^{3}$, \\ VOLODYMYR VAKULENKO ${ }^{3}$, OKSANA BABENKO ${ }^{4}$, KATERYNA PROTSAK ${ }^{5}$ \\ ${ }^{1}$ Department of Information Economics, Entrepreneurship and Finance, ZAPORIZHZHIA NATIONAL UNIVERSITY, \\ UKRAINE. E-mail: nat.metelenko@ukr.net \\ ${ }^{2}$ Department of Politology, Administration and State Security, LESYA UKRAINKA VOLYN NATIONAL UNIVERSITY, \\ UKRAINE \\ ${ }^{3}$ Department of Regional Administration, Local Self-Government and Urban Management, NATIONAL \\ ACADEMY OF PUBLIC ADMINISTRATION UNDER THE PRESIDENT OF UKRAINE, UKRAINE \\ ${ }^{4}$ Department of Management, STATE HIGHER EDUCATIONAL INSTITUTION «DONBASS STATE PEDAGOGICAL \\ UNIVERSITY», UKRAINE; SLOVYANSK PEDAGOGICAL LYCEUM, UKRAINE \\ ${ }^{5}$ Department of Management of Organizations, LVIV POLYTECHNIC NATIONAL UNIVERSITY, UKRAINE
}

\begin{abstract}
A networked economy is an environment in which any company or individual in any economic system can contact with minimal cost with any other company or individual about teamwork, trade, exchange of ideas, or just for fun. The networked economy sets the vector along which socio-economic systems of micro, meso, macro levels will develop in the long term, which necessitates research and comprehensive analysis of digital transformation processes. The authors analyzed the essence of the network economy and its impact on the sphere of management, analyzed the current state of the Ukrainian system of public administration in the network economy's conditions and identified the main problematic tasks. Based on the analysis, the authors identified goals for the main areas of public administration and proposed a scheme for the organizational transformation of the public administration system in a networked economy. The authors also proposed a system of indices to assess the state of transformation of the public administration system in a networked economy and identify development trends.
\end{abstract}

Keywords: management information systems, network economy, public administration.

JEL Classification: D85, H83, E71

Recibido: 11 de Marzo de 2021

Aceptado: 22 de Marzo de 2021 


\section{Introduction}

In current conditions, within the framework of forming the "network economy" system, public administration's advanced functions are implemented as a critical factor in increasing the level of efficiency of all economic structures of modern society (Fedorova, 2019; Bakaeva et al., 2021). The main components of electronic digital support of financial processes are being created to accelerate the flow of information data, which serves as the basis for resource support for management systems functioning within the framework of the activities of state and municipal bodies regulating socio-economic relations, subjects of the public sector of the economy, as well as enterprises and organizations.

A qualitatively new set of economic relations is being formed, based on the provision of state and municipal services in electronic digital format, which is one of the main conditions for increasing the degree of effectiveness of publicly functioning administrative entities' activities.

The current stage of public administration in Ukraine is characterized by the emergence of new institutions that directly or indirectly take over or receive, through the delegation procedure, a set of functions that cannot effectively perform public authorities due to objective and/or subjective circumstances (Kumar, 2020). Such institutions are usually public organizations: industry associations, political parties, large business associations, professional associations, unions, etc. In essence, the list of such associations creates a separate type of public administration entities that actively influence society's development.

Thus, the modern transformation of the functioning of public administration bodies is expressed in the development and expansion of the range of application of various digital technologies, which make it possible to receive quickly, transform and transmit information messages as initial resources for the development of management decisions of a public administration, socio-economic and private-entrepreneurial nature.

One of the significant obstacles to the digital transformation of public administration remains the problem of ineffective distribution of state powers and the lack of interconnection between the assigned functions and the material, human and financial resources allocated to the authorities, which is why the chosen research topic is relevant.

\section{Research methods and models}

\subsection{The networked economy and its impact on the sphere of governance}

A networked economy is an environment in which any company or individual in any economic system can contact with minimal cost with any other company or individual about teamwork, trade, exchange of ideas, or just for fun (Salder, 2020; Salamova, 2020).

The concept of a networked economy arose in using various information networks (Fig. 1).

The following trends in the development of the network economy can be noted (Sekreter

2017; Samoilenko \& Bohdan, 2019; Belikova, 2020):

- individual approach;

- the emergence of global competition, in which quality, level of service are essential;

- availability of information intermediaries;

- reduction in transaction costs, marketing costs, communications, etc.;

- changes in the structure of existing organizations;

- process automation. 
Figure 1. Main characteristics of the network economy

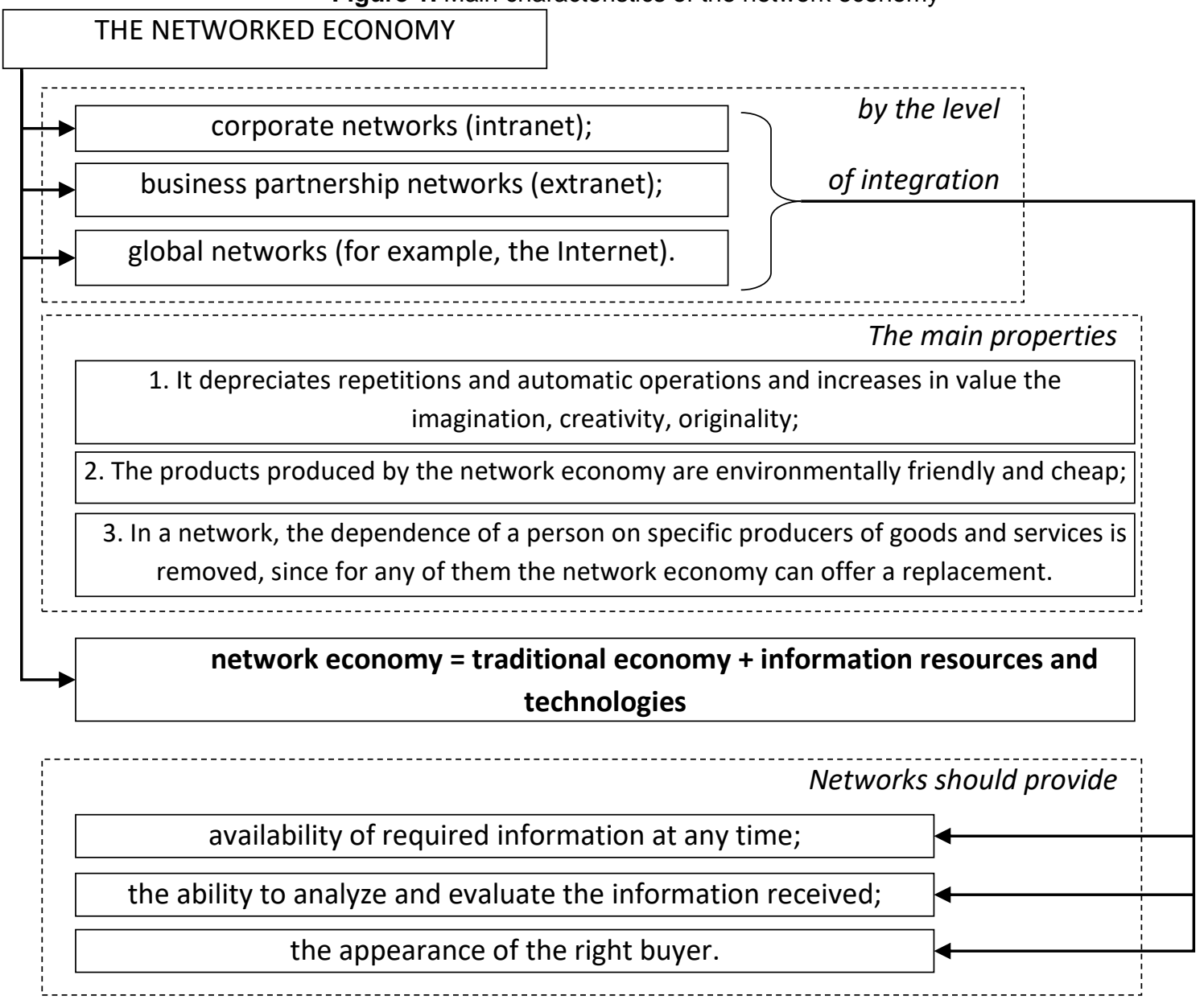

The networked economy concept is associated with the creation and modernization of software, computer chips, mobile communications, etc. (Samoilenko \& Bohdan, 2019; Belikova, 2020; Gojayeva et al., 2021). In general, those types of human activities that relate to technical progress in information technology.

At present, the network economy is closely related to those spheres of the economy, which depends significantly on the degree of use of information technologies in production processes. These include e-commerce, banking, and more.

Based on the preceding, it is logical and justified to conclude that the network economy is a new economic reality characterized by the following circumstances: the digital economy is the final stage of globalization, in which all the world's wealth and resources are digitized; the formation of new channels inside and outside of systemic interactions based on platforms is carried out; there is a change in the model for calculating efficiency - from produced wealth to completed transactions; a difference in the management paradigm is planned: from a hierarchy of managers to an order of algorithms and platforms (Fig. 2).

Also, the functions of a manager undergo a significant transformation in the digital economy:

- creation of control algorithms for digital platforms;

- implementation of control algorithms;

- optimization of control algorithms. 
Figure 2. Evolution of the concept of management in a networked economy

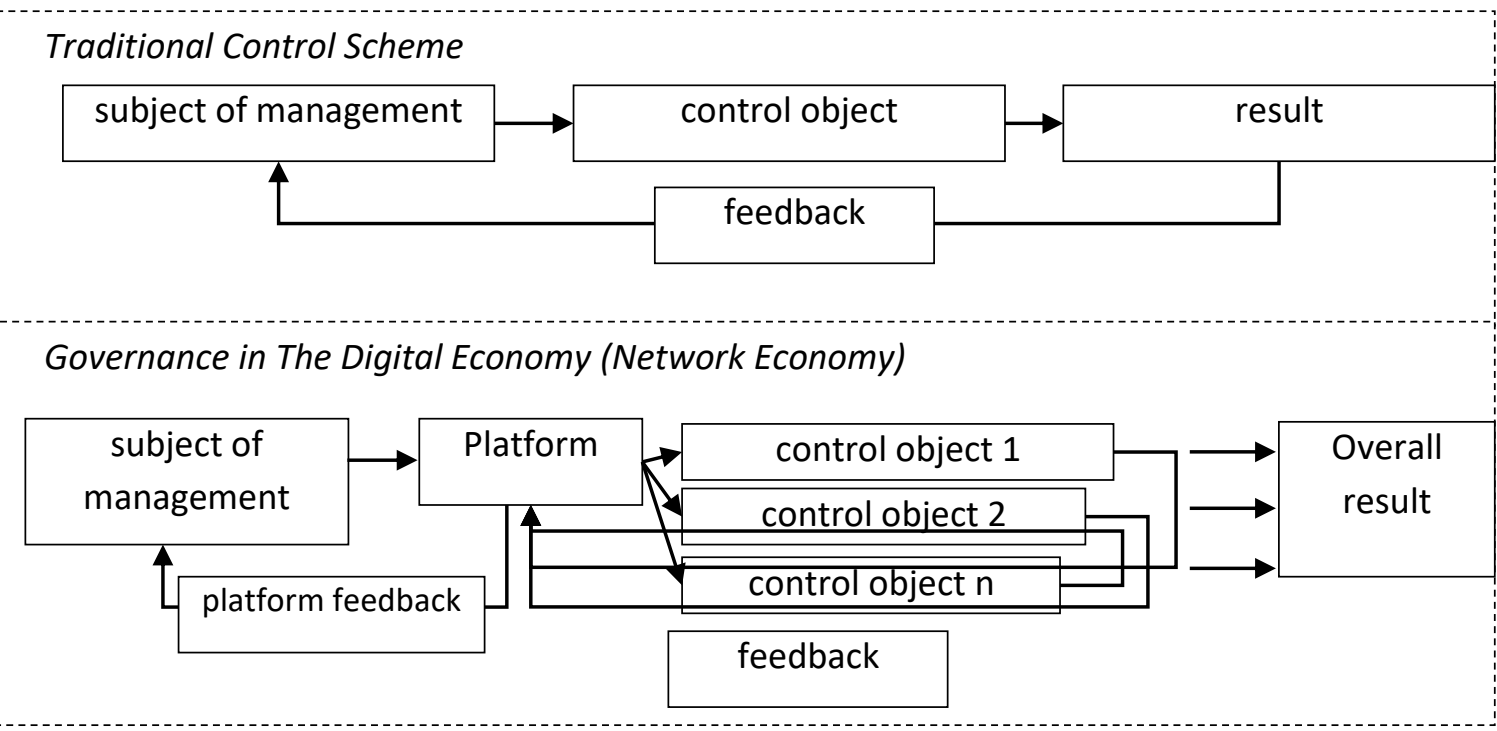

\subsection{The current state of the Ukrainian system of public administration in a networked economy}

Improving public authorities' efficiency and local self-government is one of the sustainable development tasks (Fig.3).

According to our forecast, if the dynamics are maintained, Ukraine in 2020 should strive to be in 97th place and at 85th in 2021.

The most breakthrough in digitalization of public administration services is the introduction of the "Diia" application. "The State and I" (ukr: "Diia") is a Ukrainian electronic service of public services. It includes a web portal with public services online and a mobile application. The application was launched in winter 2020, during which time 2.3 million Ukrainians have already downloaded it. The portal is available from 15 April. The project's presentation took place on February 6, 2020, and the portal of public services "Diia" is available to Ukrainians from April 2. This is actually the only electronic cabinet of all public services without bureaucracy.

There are two ways to use the service:

- download the "Diia" program on a mobile phone. The Android operating system application can be downloaded from Google Play and for the IOS operating system - from the AppStore.

- use the "Diia" portal.

You also need to go through identity verification.

Figure 3. Ukraine's place in the Global Competitiveness Report ranking under the sub-index "Institutions (state and public institutions)"

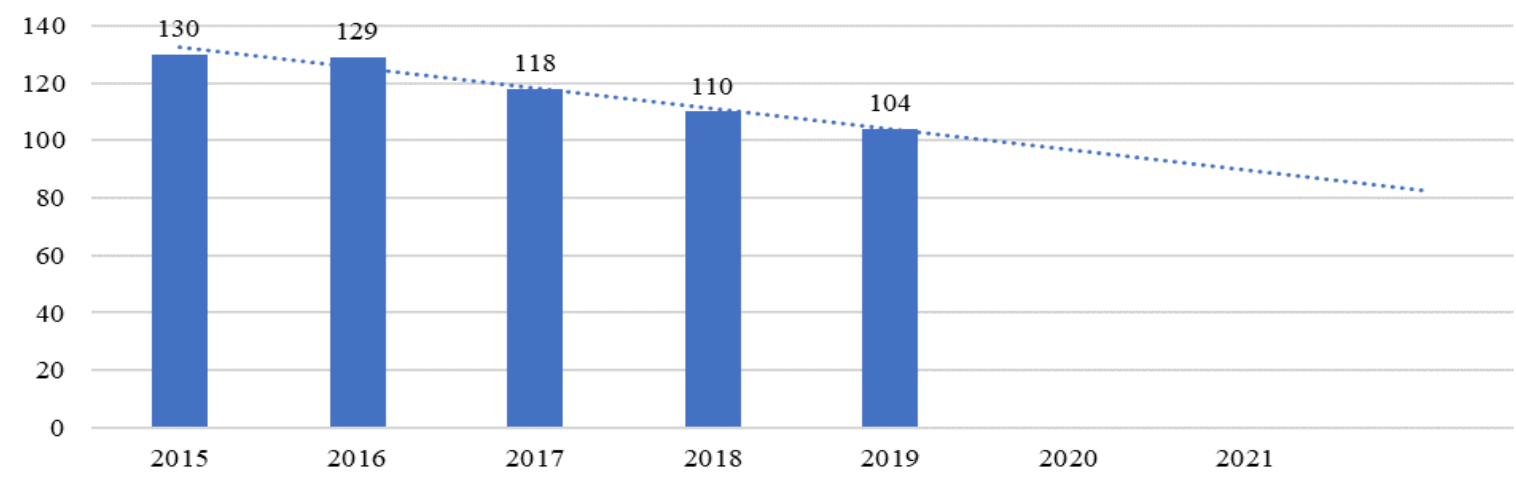


For January 2021, the following electronic documents are available in the "Diia" application: digital ID-cards; international passport; electronic driver's license; auto insurance; student card; personal tax number; birth certificate; fines for traffic violations; enforcement proceedings.

In the plans: replacement of driver's license; sharing of technical passport; taxes; Smart "Diia", etc.

The developers also plan to use the application in the elections. Electoral registers are planned to be added by the end of the year. Diya is a well-secured platform. It is located in a reliable data centre and meets world standards for protection against cyber threats. In addition, "Diia" stores a minimum of information about its users, the portal states. On mobile phones with an operating system, Android can't even take a screenshot of a document.

A digital passport has the same legal effect as paper passports and ID cards. On April 15, the Cabinet of Ministers of Ukraine adopted a resolution. On the implementation of a pilot project on using a passport of a citizen of Ukraine in the form of an electronic card and a passport of a citizen of Ukraine for travelling abroad in electronic form. A foreign passport provides the same rights and opportunities as a national one, but so far it works only on the territory of Ukraine.

For the quarantine period, the application worked to confirm self-isolation. "'Diia.Home". Instead of compulsory observation for several citizens, the Cabinet of Ministers introduced self-isolation with enhanced control using an application. Diya.Home is a closed program and is installed only in smartphones of persons who have potentially had contact with patients and are registered in medical institutions as those who must observe the regime of self-isolation. Monitoring - through the removal of geolocation and FacelD in a random period.

Functional: registration at the place of self-isolation; photo confirmation of stay at the home of self-isolation; an emergency call to the hotline of the Ministry of Health of Ukraine.

The driver's license can be shown when stopped by the police. The app generates a QR code that patrol officers scan and can check a driver's license, insurance or car owner.

Several projects are also working based on the "Diia" service:

Public services portal "Diia" - on the portal you can already get 27 public services, in particular, to become an entrepreneur, change the type of activity or stop it.

"Diia. Digital education" is a series of video tutorials that should increase the digital literacy of Ukrainians.

"Diia.Business" - site for small and medium business entrepreneurs. The portal functions as an information platform and an online consultation service.

"eMalyatko" (eBaby) portal is a comprehensive service for parents of newborns. According to one application in the maternity hospital, the registry office or the Central Statistical Office, the baby's parents can receive up to 8 services.

For the rest, the digitalization of the public administration system is relatively low.

Even the State Statistics Committee provides information only on the number of public authorities and local governments that allow the use of e-democracy tools, by groups of institutions and the use of e-democracy tools by public authorities and local governments by groups of institutions (Fig. 4).

Building a network society in Ukraine should provide a sufficient information space, which is the basis of the country's security, its socio-economic, political and cultural development, and will be the key to entering the global information space.

It should be noted that the means of information interaction of citizens and organizations that provide them with access to information resources are based on appropriate information technologies, such as software and hardware and organizational and regulatory documents. Thus, the information and telecommunication infrastructure is formed by organizational structures and means of information interaction. A characteristic feature of the process of creating a single information space of Ukraine is not only the creation of technologies and technological structure of 
informatization to ensure the interaction of information producers and consumers, the distribution of knowledge accumulated in information data banks, but also social, economic and political aspects of its formation and integration world information space.

Figure 4. Use of e-democracy tools by public authorities and local governments by groups of institutions (State Statistics Service of Ukraine, 2021)

state organizations (institutions, establi shments)

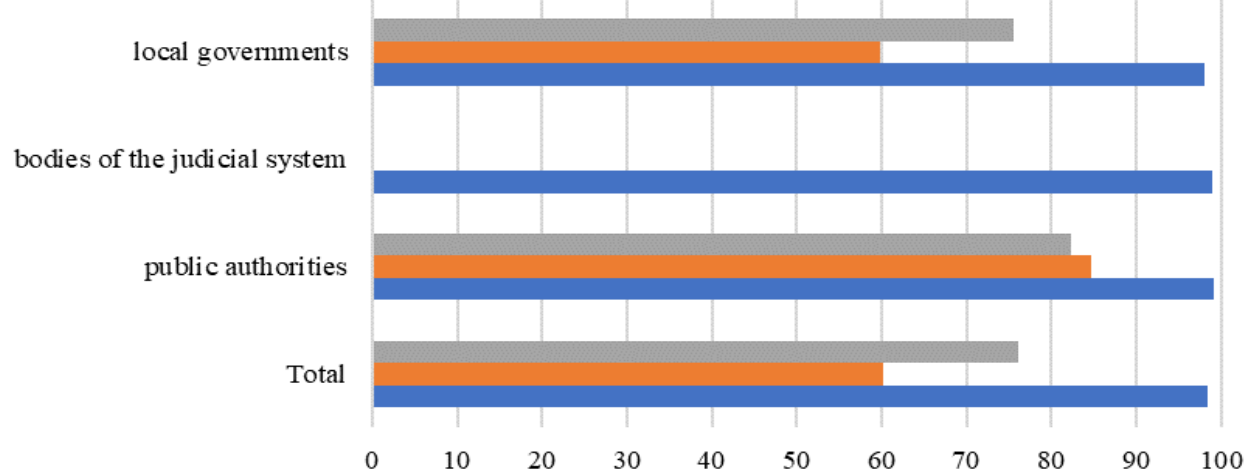

- Share of "Participation budget (public budget)" projects implemented at the expense of the local budget in the reporting year in the total number of supported projects (winning projects) "Participation budget (public budget)",\%

- Share of "E-petitions" supported by the decisions of the bodies to which the petitions are addressed in the total number of supported (who received the required number of votes in support) "E-petitions",\%

- Share of considered "E-appeals" in the total number of registered "E-appeals",\%

However, it is worth noting new trends in the development of public service: focus not only on bureaucratic (rationalism, responsibility, professionalism, loyalty, diligence, accuracy) but also on democratic values (service to the public good, protection of human rights, citizenship, social justice), aspirations the public service of Ukraine to the transition from bureaucratic leadership (due not so much to the personal virtues of the leader) to the transformation, as its position in the bureaucratic hierarchy) to ethical leadership, which is based on the unique moral authority of leaders.

\subsection{Highlighting problematic tasks}

Among the unresolved and most problematic tasks, we identified the following:

- imbalance in the system of distribution of state powers, the organizational structure of state bodies and interactions between them;

- ineffectiveness of budgetary expenditures for the maintenance of the state apparatus and performance of functions;

- insufficient level of labour productivity in the executive authorities, which is compensated by the excess number of employees;

- low level of modern digital competencies and professional qualifications of civil servants;

- the state apparatus's lack of commitment to values such as efficiency, accountability, and serving the public interest. Here are some illustrative examples based on the analysis of the experience of the previous stages of reforming the public administration system.

Confirmation of the European course of development of the state obliges Ukraine to implement immediate and consistent changes in public administration system, focusing it on the satisfaction of the rights and interests of citizens, in particular: by providing quality administrative services. 


\section{Results and discussion}

An analysis of Ukrainian and foreign practice and theoretical studies shows that serviceization and digital transformation of socio-economic systems are carried out based on digital platforms that integrate economic, social and technological processes that form digital service ecosystems. In this regard, a new institution is emerging in the economy, a new category of business structures in the service sector - service integrators, whose role in progressive economic development is significantly increasing, but the mechanisms of their functioning, methods of management, network service interaction with other economic entities, as well as many others the issues remain insufficiently studied, which in practice hinders the development of companies - service integrators.

Before making key decisions on the public sector's digitalization, it is fundamentally important first to identify digital transformation goals and determine the target state and expected effects. For the main areas of public administration, we propose the following goals:

1) reduction of costs for the activities of government agencies - by optimizing supporting, invariant functions (back offices of government agencies);

2) increasing the productivity of civil servants in the provision of public services and the implementation of control and supervision activities - through standardization and modernization of administrative and management processes;

3 ) reducing the cost of creating and administering information resources and systems - due to the reuse of information technologies and services;

4) increasing the efficiency of budgetary expenditures on program (project) activities implemented by the authorities - by promoting and stimulating the introduction of digital technologies in sectors of the economy;

5 ) increasing the level of confidence of citizens and business in government bodies and officials, supporting their decisions (policies) - through the formation of an ecosystem of public and private platforms.

The digital public administration model must meet the requirements of specific periods of development of the information society. Organizational design of such a model should be carried out in the following sequence (Fig. 5).

Considering the digital public administration model as a modern form of public administration is essential to see its priority - ensuring access to all public information. This, in turn, stimulates the development of the services sector, based on the introduction of new sources of socially significant information into civil circulation.

To assess the state of transformation of the public administration system in a network economy and identify trends in the information society in general, especially its technical and technological component, requires an integrated system of indicators based on data: state statistical accounting; on the results of special empirical studies of the market of information and communication technologies conducted by Ukrainian and foreign companies; taking into account the ratings of such international organizations as the UN, the EU, the World Bank, ITU, OECD, etc. (Benkler, 2017; Prokopenko \& Omelyanenko, 2020).

In addition to the system of indicators, monitoring methods, analyzing and forecasting the situation in this area in the short, medium and long term should be developed and officially approved and appropriate resources for information and analytical support and a set of sources and users of information., established regulations for their interaction and information requirements, i.e. a system of information and analytical support should be created. There is no such system in Ukraine, which has a significantly negative impact on public policy and public administration's effectiveness in this area, which are implemented in the absence of feedback and are based mainly on inaccurate, incomplete and contradictory statistics, intuitions and previous experience making strategic decisions. 
Natalya Metelenko, Liudmyla Pashko, Nataliia Grynchuk, Volodymyr Vakulenko, Oksana Babenko, Kateryna Protsak

Figure 5. The scheme of organizational transformation of public administration in a networked economy

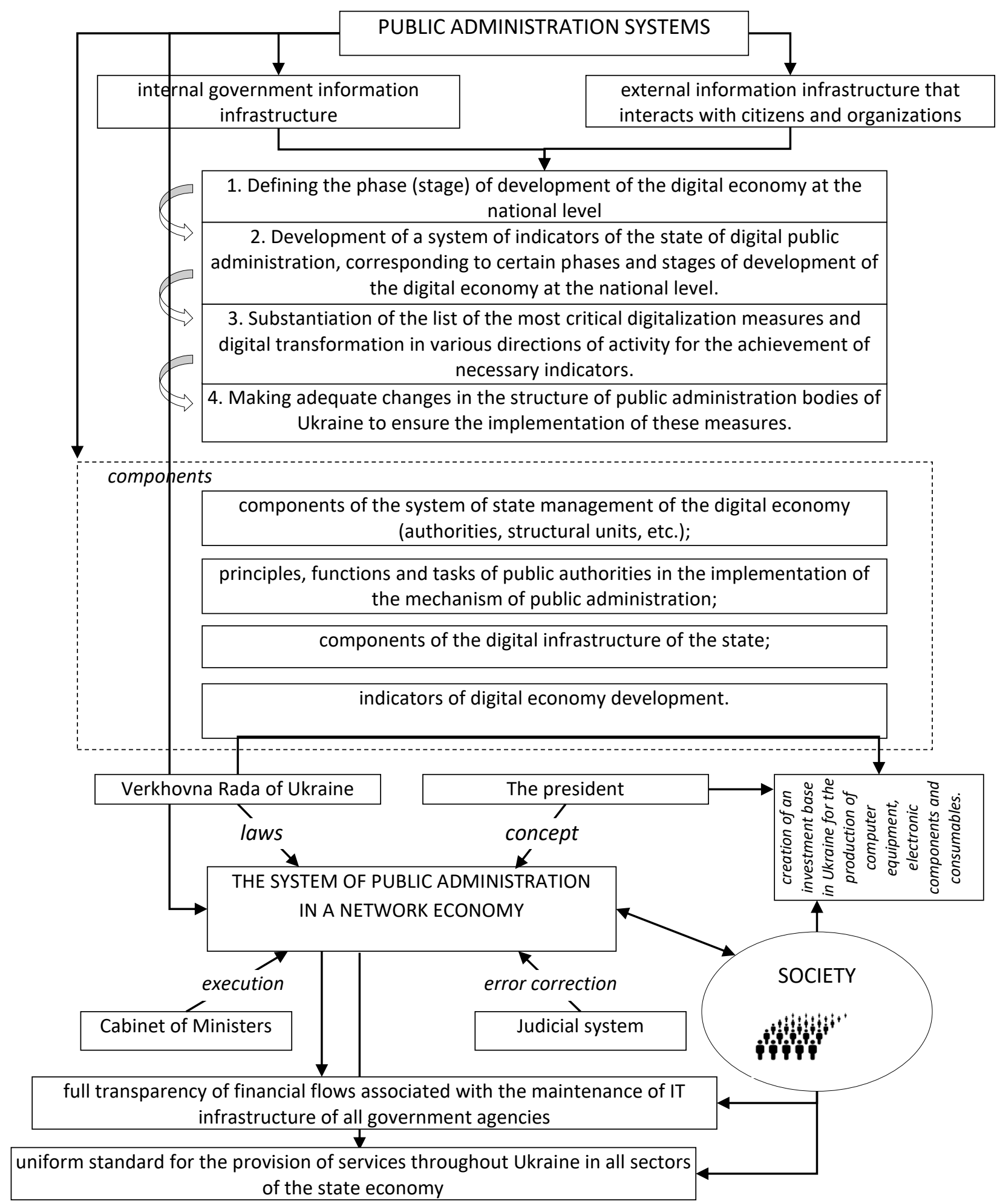

There are more than twenty international e-indexes in the world, but the most widely used are:

- E-Government Development Index (EGDI) is a comprehensive indicator that assesses government agencies' ability to use ICT to provide public services to citizens. The index is developed by the UN and is issued every two years. It includes three groups of indicators: 1) the degree of coverage and quality of Internet services, 2) the level of development of ICT infrastructure, 3) human capital. 
- Digital Opportunity Index (DOI), developed by the ITU within the WPIIS; measures ICT capabilities through the analysis of infrastructure, availability and coverage, and quality. It is evaluated based on three sub-indices: 1) opportunities, 2) infrastructure, and 3) use.

- Digital Access Index (DAI), ITU; an indicator that measures the overall access and use of ICTs for citizens. The index was developed in 2003 by the ITU Information and Statistics Markets Division and is calculated for 181 countries. DAl is based on four components: 1) infrastructure, 2) accessibility, 3) knowledge and quality, 4) the actual use of ICT.

- Information Society Index (ISI), IDC; characterizes the development of information technologies, opportunities for dissemination and availability of information in 53 countries. ISI has been calculated and published by two organizations, the World Times and the International Data Corporation (IDC), since 1997. The ISI index is calculated based on 15 indicators grouped into four categories: 1) computers, 2) telecommunications, 3) internet, 4) social development.

- indices of the Harvard methodology for assessing the network world, etc.

To increase the reliability, accuracy and reliability of data is advisable to combine them from various sources and ensure their provision to users by their requirements for the quality of relevant information. To this end, it is necessary to coordinate the various actors involved in solving this problem.

\section{Conclusion}

Summarizing the analysis of the transformation of public administration into modern systems of social regulation, which takes place in developed countries, it should be noted: Ukraine, as a country that has chosen the European vector of development, must move innovatively to improve governance in the public sector. When enhancing the field of public administration, it is desirable to study the best foreign trends and practices, take into account the positive results and use them, adapting to national characteristics. All these steps must meet citizens' expectations and form a governance model that balances the interests of the main participants in the social process.

At the present stage, Ukraine is just beginning the path of digital transformation by the requirements of the digital economy, while most areas are already approaching global standards of digital governance. Thus, the need to develop a comprehensive model of public administration in the framework of digitalization and digital transformation is beyond doubt. Based on the substantiation of positive foreign experience, it is possible to state the expediency of introducing a new model of digital public management in Ukraine, which would take into account all the challenges of the network economy. The fundamental problem of further research may be that the new model's central body will not be able to deal with all the issues that will arise concerning decision-making due to the implementation of such a model. At the same time, there is a high probability of a shortage of specialized managers with modern managers' professional functions.

\section{References}

1. Bakaeva, Z. et al. (2021). Economic Processes in the Conditions of Digitalization of Modern Society. SHS Web of Conferences 93:01012. DOI: 10.1051/shsconf/20219301012

2. Belikova, K. (2020). The Implications Of Network Economy In The Field Of Competition. Journal of Advanced Research in Dynamical and Control Systems, 12(6), pp. 532-540. DOI: 10.5373/JARDCS/V12SP6/SP20201061

3. Benkler, Y. (2017). Law, Innovation, and Collaboration in Networked Economy and Society. Annual Review of Law and Social Science, 13(1), pp. 231-250. DOI: 10.1146/annurev-lawsocsci-110316113340 
4. Fedorova, N. (2019). Informatization of modern society and its socio-economic consequences. Economic Bulletin, 1(9), pp. 13-23. DOI: 10.32434/2415-3974-2019-9-1-13-23

5. Gojayeva, E. et al. (2021). Information Platforms and the Global Network Economy. SHS Web of Conferences, 92(5):04007. DOI: 10.1051/shsconf/20219204007

6. Kumar, K. (2020). From Post-Industrial to Post-Modern Society, In book: The Information Society Reader. DOI: $10.4324 / 9780203622278-13$

7. Prokopenko, O. \& Omelyanenko, V. (2020). Intellectualization of the phased assessment and use of the potential for internationalizing the activity of clusters of cultural and creative industries of the Baltic Sea Regions. TEM Journal, 9(3), pp. 1068-1075.

8. Salamova, A. (2020). Global networked economy as a factor for sustainable development. E3S Web of Conferences 208:03053. DOI: 10.1051/e3sconf/202020803053

9. Salder, J. (2020). The networked economy of firms in city-region peripheries. European Urban and Regional Studies, pp. 1-18. DOI: 10.1177/0969776420975845

10.Samoilenko, A. \& Bohdan Y. (2019). Network economy development in the context of globalization processes, Ekonomika ta Derzhava, 10, pp. 93-97. DOI: 10.32702/23066806.2019.10.93

11.Sekreter, A. (2017). Optimization in a Networked Economy. International Journal of Social Sciences and Educational Studies, 4(1), pp. 115-119. DOI: 10.23918/ijsses.v4i1p115

12.State Statistics Service of Ukraine (2021). [online]. Available at: http://www.ukrstat.gov.ua/ [Accessed 03 January 2021]. 